\title{
Comparison of clinical course of Acute Biliary and Non- Biliary Pancreatitis
}

\author{
Abishek Bhattarai ${ }^{1}$, Pragya Devkota ${ }^{2}$, Bishnu Prasad Kandel ${ }^{3}$, Bikal Ghimire ${ }^{3}$, Prasan Bir Singh Kansakar ${ }^{3}$, \\ Ramesh Singh Bhandari ${ }^{3}$, Kishor Kumar Tamrakar ${ }^{4}$, Palaswan Joshi Lakhey ${ }^{3}$, Parshuram Mishra ${ }^{3}$, Yogendra \\ Prasad Singh $^{3}$, Pradeep Vaidya ${ }^{3}$, Keshaw Prasad Singh ${ }^{3}$ \\ ${ }^{1}$ Department of Surgery, Maharajgunj Medical Campus, Tribhuvan University Teaching Hospital, Nepal \\ ${ }^{2}$ Resident, Department of Pharmacology, Maharajgunj Medical Campus, Tribhuvan University Teaching Hospital, Nepal \\ ${ }^{3}$ Department of Surgery, Maharajgunj Medical Campus, Tribhuvan University Teaching Hospital, Nepal
}

${ }^{4}$ Chitawan Medical College, Bharatpur Chitawan

Correspondence: Dr Abhishek Bhattarai, Department of Surgery, Maharajgunj Medical Campus, Tribhuvan University Teaching Hospital

Email: abhishekbhattarai@gmail.com

Abstract

Introduction: Incidence of acute pancreatitis (AP) varies in different parts of the world. The published data are mainly based on retrospective analysis of hospital admissions, which show that there are considerable geographical differences in the incidence rate. There are also regional divergences with regard to the etiology, and its impact on morbidity and mortality. Therefore, we compare the clinical course of acute biliary and non-biliary pancreatitis at the Tribhuvan University Teaching Hospital (TUTH) as well as we compare the morbidity and mortality and duration of hospital stay in these groups.

Methods: This prospective study included the patients with a diagnosis of AP over a period of one year. Eighty-five patients with the diagnosis of AP were included in the study. Revised Atlanta classification system (2012) was used to diagnose and define the severity of disease. The occurrence of local and systemic complications, median duration of hospital stay and mortality in AP was studied.

Results: Among 85 patients, 34 patients were females and 51 were males. Among them, 46 patients belonged to the biliary group and 39 belonged to the non-biliary group. Alcohol intake was the major etiology in the non-biliary group $(n=26)$ and all of them were male. The majority of the gallstone induced AP patients were female $(n=29)$. Twenty-nine patients developed severe acute pancreatitis (SAP: 16 in biliary and 13 patients in non-biliary group). Complications were mostly seen in SAP. The acute fluid collection was the most common local complication (15 patients in biliary and 15 patients in non-biliary group, $\mathrm{p}>0.05)$ and respiratory failure was the most common systemic complication (18 patients in biliary and 16 patients in non-biliary group, $\mathrm{p}>0.05$ ) in both groups. Three patients in biliary group and four patients in non-biliary group died due to multi-organ failure $(\mathrm{p}>0.05)$. There was no statistical significant difference in the median duration of hospital stay in these groups.

Conclusion: Though pathogenesis vary for different etiologies, once the disease process has started, local complications, systemic complications, duration of hospital stay and mortality in AP depends on the severity of the disease irrespective of the etiology.

Key words: Acute Pancreatitis; Biliary Pancreatitis; Non-Biliary Pancreatitis. 


\section{Introduction}

Acute pancreatitis (AP) is a common cause of acute abdomen with variable risk factors, and wide range of severity from mild self-limiting disease to a severe rapidly progressive illness leading to multi organ failure and death. ${ }^{1}$ About $15-20 \%$ of the patients with a history of AP can progress to severe acute pancreatitis associated with local and systemic complications. ${ }^{2}$ There are no actual prevalence data available in our country. However hospital based data showed an annual incidence of 60 to 90 patients per year at tertiary care center in Kathmandu. ${ }^{3,4}$

Two major etiological factors responsible for AP are gallstone and alcohol. ${ }^{5}$ Other risk factors include endoscopic retrograde cholangiopancreatography (ERCP), trauma, drugs, surgery, malignancy, viral infection, hyperlipidemia, and biliary tract anomalies. ${ }^{1}$ Idiopathic pancreatitis (IP) is described as pancreatitis in which the etiological factor cannot be diagnosed. ${ }^{6}$ The incidence of IP ranges from 4.21 per 100000 to as high as 45.33 per $100000 .^{6}$

There was no universally accepted definition, classification and severity grading of the AP in the past. Atlanta symposium was first convened in 1992 attempted to provide the common terminology and define the severity of the disease with a uniform classification for the first time and it was revised \& updated in 2012. This new definition and classification system addresses the diagnosis, types and severity of AP, and definition of pancreatic and peripancreatic collections. ${ }^{7}$

In spite of numerous advances in diagnosis and treatment of AP in the recent years, ability to predict outcome remains challenging. Several scoring systems have been proposed for the assessment of the severity, including Ranson score, Glasgow score, BISAP score and APACHE, SIRS score by different authors to predict the severity and outcome following AP. ${ }^{8}$ None of them are accurate to predict morbidity and mortality.

Generally, it is believed that, though the pathogenesis is different for different etiology, once the disease process has started mortality depends on the severity of the disease. There are several publications regarding the impact of etiology on the outcome of the AP. The published data are mainly based on retrospective analysis of hospital admissions, which showed that there are considerable geographical differences in the incidence rate as well as etiology, and its impact on morbidity and mortality. Some authors deny a relationship of mortality and morbidity with etiology whereas others describe the relation..$^{9-17}$ Therefore, we compare the clinical course of acute biliary and nonbiliary pancreatitis at the Tribhuvan University Teaching Hospital (TUTH) as well as we compare the morbidity, duration of hospital stay and mortality in these groups so that we could detect difference in characteristics that could be relevant for the prognosis and therapy.

\section{Methods}

Patients with a diagnosis of AP admitted in the surgical ward of Tribhuvan University Teaching Hospital over a period of one year (2070/05/01 to 2071/04/30) were studied. Patients of age less than 18 years, post ERCP pancreatitis, recurrent acute pancreatitis were excluded. Diagnosis of acute pancreatitis, its severity, local and systemic complications were defined as per revised Atlanta classification 2012. Modified Marshall Score was determined at admission, and at 48 hours of hospital admission.

Biliary etiology was confirmed as the cause of AP in patients with a history of cholecystectomy or with CBD exploration or detection of gall bladder of bile duct stone on imaging. Combination of age, sex and laboratory markers (system 4) was used in case of difficulty to predict a biliary etiology. ${ }^{18}$

Alcoholic etiology was defined on the basis of a history of chronic alcohol intake or recent alcohol intake in the week prior to admission while AP of other etiologies were excluded. ${ }^{15,19}$

Other etiologies were diagnosed on the basis of the history and examination of the patients. When a diagnosis could not be made through a history, physical examination, laboratory studies, and imaging modalities those cases were designated as idiopathic pancreatitis.

The data were analyzed using Statistical Package for Social Sciences (SPSS) for Windows version 19. Chi square test was used for categorical variables, and t-test was used for continuous variables. P-value $<0.05$ was considered clinically significant.

\section{Result}

Within the study period, a total of eighty five patients were included in the study. Forty six (54\%) patients were admitted with biliary etiology and 39 (46\%) with nonbiliary etiology. (Table 11) Among non-biliary patients, alcohol induced pancreatitis was the most common $(n=26)$. In $5 \%$ of the cases etiology could not be identified $(n=4)$. 
Table 1: Etiology of acute pancreatitis

\begin{tabular}{|c|c|}
\hline Total No. of pts. & $\mathrm{n}=\mathbf{8 5}$ \\
\hline Biliary & $46(54 \%)$ \\
\hline Non biliary & $39(46 \%)$ \\
\hline Alcohol & $26(31 \%)$ \\
\hline Drug induced & $3(3.5 \%)$ \\
\hline Trauma & $3(3.5 \%)$ \\
\hline Malignancy & $2(2 \%)$ \\
\hline Mumps & $1(1 \%)$ \\
\hline Others & $4(5 \%)$ \\
\hline
\end{tabular}

\section{Age and gender}

The age of the patients ranged from 21 to 85 years. The mean age was $46.15 \pm 15.75$ years for biliary and $40.23 \pm 15.65$ years for non-biliary group ( $\mathrm{P}$ value $>0.05$ ). Biliary pancreatitis was predominantly seen in female $(\mathrm{n}=29)$, whereas non biliary was mostly seen in male $(n=34)$. (Table 2$)$

Table 2: Age and gender distribution of the patients

\begin{tabular}{|c|c|c|c|}
\hline & $\begin{array}{l}\text { Biliary } \\
(n=46)\end{array}$ & $\begin{array}{l}\text { Non biliary } \\
(n=39)\end{array}$ & $p$ value \\
\hline Male & $17(37 \%)$ & $34(87 \%)$ & 0.001 \\
\hline Female & $29(63 \%)$ & $5(13 \%)$ & 0.001 \\
\hline $\begin{array}{l}\text { Mean age } \\
\text { (year) }\end{array}$ & $46.15 \pm 15.75$ & $40.23 \pm 15.65$ & 0.087 \\
\hline
\end{tabular}

\section{Severity}

About $53 \%$ of the patients belonged to the mild group, 13.0 $\%$ in moderate group and $34.0 \%$ in severe group. There was no statistical difference in the incidence of severity among the biliary and non-biliary groups. (Table 3 )

Table 3: Distribution of patients, according to severity

$\begin{array}{llll}\text { Severity } & \begin{array}{l}\text { Biliary } \\ (\mathbf{n}=46)\end{array} & \begin{array}{c}\text { Non biliary } \\ (\mathbf{n}=39)\end{array} & \text { Total } \\ \text { Mild (52.94\%) } & 26(56.5 \%) & 19(48.7 \%) & 45 \\ \begin{array}{l}\text { Moderate } \\ (12.94 \%)\end{array} & 4(8.6 \%) & 7(17.9 \%) & 11 \\ \begin{array}{l}\text { Severe } \\ (34.11 \%)\end{array} & 16(34.7 \%) & 13(33.3 \%) & 29 \\ \text { Total } & 46 & 39 & 85\end{array}$

Patients with MAP had a median duration of hospital stay of 4 days (range of 4-6 days for biliary and 4-5 days for non-biliary group). Whereas in moderate group it was 6 days (6-9 days) for biliary and 7 days (6-17days) for nonbiliary group. For severe group it was 10 (9-60) days for biliary and 13 (7-30) days for non-biliary pancreatitis.

\section{Diagnostic criteria}

Twenty nine out of forty six $(63.0 \%)$ in biliary group and 22 out of $39(56.4 \%)$ had a history of a typical pancreatic type of pain. The pancreatic enzymes amylase and lipase were significantly raised in both groups. Whereas USG was less reliable to diagnose acute pancreatitis during an emergency. (Table 4)

\section{Table 4: Diagnostic criteria of AP}

\begin{tabular}{llll} 
& $\begin{array}{l}\text { Biliary } \\
(\mathbf{n}=\mathbf{4 6})\end{array}$ & $\begin{array}{l}\text { Non biliary } \\
(\mathbf{n}=\mathbf{3 9})\end{array}$ & $\boldsymbol{p}$ value \\
\hline Typical pain & $29(63 \%)$ & $22(56.4 \%)$ & 0.534 \\
Raised amylase /lipase & $38(82.6 \%)$ & $35(87.7 \%)$ & 0.533 \\
USG & $16(34.7 \%)$ & $14(35.8 \%)$ & 0.914
\end{tabular}

\section{Local complications}

Fifteen $(32.60 \%)$ out of 46 patients in biliary group and 15 out of $39(38.46 \%)$ patients in non-biliary group developed local complications. Eleven patients $(23.91 \%)$ in biliary group and 8 patients $(20.51 \%)$ in non-biliary group developed pancreatic necrosis ( $p$ value $>0.05$ ). (Table 5) There was no statistical difference in the incidence of peri-pancreatic collection, infected and sterile pancreatic necrosis, pancreatico- peritoneal fistula and vascular aneurysm in biliary and non-biliary groups.

Table 5: Incidence of local complications in Biliary and Non-biliary pancreatitis

$\begin{array}{llll}\text { Local Complications } & \begin{array}{l}\text { Biliary } \\ (\mathrm{n}=46)\end{array} & \begin{array}{l}\text { Non biliary } \\ (\mathrm{n}=39)\end{array} & p \text { value } \\ \text { Acute fluid collection } & 15(32.6 \%) & 15(38.4 \%) & 0.574 \\ \text { Necrosis } & 11(23.9) & 8(20.5 \%) & 0.233 \\ \quad \text { Sterile } & 7(15.2 \%) & 7(17.9 \%) & 0.753 \\ \quad \text { Infected } & 4(8.6 \%) & 1(2.5 \%) & 0.231 \\ \text { Pseudo aneurysm } & 1(2.1 \%) & 0 & 0.231 \\ \begin{array}{l}\text { Pancreatico-peritoneal } \\ \text { fistula }\end{array} & 1(2.1 \%) & 3(7.6 \%) & 0.231\end{array}$




\section{Systemic complications}

Respiratory failure was the most common organ failure followed by renal and cardiovascular failures with the similar incidence rate ( $\mathrm{p}$ value $>0.05$ ) in both groups. (Table 6)

Table 6: Incidence of systemic complications in Biliary and Non biliary pancreatitis

\begin{tabular}{|c|c|c|c|}
\hline & $\begin{array}{l}\text { Biliary } \\
(n=46)\end{array}$ & $\begin{array}{l}\text { Non } \\
\text { biliary } \\
(n=39)\end{array}$ & $\begin{array}{l}p \\
\text { value }\end{array}$ \\
\hline Cardiovascular failure & $6(13 \%)$ & $4(10.2 \%)$ & 0.691 \\
\hline Renal failure & $6(13 \%)$ & $4(10.2 \%)$ & 0.691 \\
\hline Respiratory failure & $16(34.7 \%)$ & $16(41 \%)$ & 0.554 \\
\hline Transient organ failure & $2(4.3 \%)$ & $4(10.2 \%)$ & 0.289 \\
\hline Persistant organ failure & $16(34.7 \%)$ & $13(33.3 \%)$ & 0.915 \\
\hline Single organ failure & $9(19.5 \%)$ & $11(28.2 \%)$ & 0.349 \\
\hline Multi organ failure & $9(19.5 \%)$ & $6(15.3 \%)$ & 0.614 \\
\hline
\end{tabular}

Similarly, there was no statistical difference in the incidence of other complications like pleural effusion, chest infection, however, there is a higher proportion of cholangitis and cholecystitis in biliary group, whereas, variceal bleeding and stress ulcer in non biliary group (table: 7).

Table 7: Incidence of other complications in Biliary and Non biliary pancreatitis

$\begin{array}{llll}\text { Complications } & \begin{array}{l}\text { Biliary } \\ \mathbf{n = 4 6}\end{array} & \begin{array}{l}\text { Non biliary } \\ \mathbf{n = 3 9}\end{array} & \boldsymbol{p} \text { value } \\ \text { Pleural effusion } & 20(43.4 \%) & 18(46.1 \%) & 0.805 \\ \text { Chest Infection } & 11(23.9 \%) & 7(17.9 \%) & 0.502 \\ \text { Stress ulcer } & 0 & 3(7.6 \%) & 0.055 \\ \text { Variceal bleed } & 0 & 3(7.6 \%) & 0.055 \\ \text { Cholangitis } & 6(13 \%) & 0 & 0.80 \\ \text { Cholecystitis } & 4(8.6 \%) & 0 & 0.231 \\ \text { Diabetes } & 6(13 \%) & 3(7.6 \%) & 0.424\end{array}$

\section{Intervention}

Some form of intervention was done in 3 patients with biliary etiology and 4 patients with non-biliary etiology. Necrosectomy, percutaneous drainage and PTBD were done for one patient in each group, whereas ERCP and stenting was done in one patient with alcoholic pancreatitis with pancreatic ascites. ( $\mathrm{P}$ value $>0.05$ ) (Table 8 )

Table 8: Total no. of Interventions done in Biliary and Non biliary pancreatitis

$\begin{array}{llll} & \begin{array}{c}\text { Biliary } \\ (\mathrm{n}=46)\end{array} & \begin{array}{c}\text { Non biliary } \\ (\mathrm{n}=39)\end{array} & p \text { value } \\ \text { Necrosectomy } & 1 & 1 & 0.906 \\ \begin{array}{l}\text { Percutaneous } \\ \text { drainage }\end{array} & 1 & 1 & 0.906 \\ \text { PTBD } & 1 & 1 & 0.906 \\ \text { ERCP + stenting } & 0 & 1 & 0.275 \\ \text { Total } & 3(6.52 \%) & 4(10.25 \%) & \end{array}$

\section{Mortality}

Three patients in biliary group and four patients in the nonbiliary group died due to MODS. ( $\mathrm{P}$ value $>0.05$ )

\section{Discussion}

Worldwide biliary and alcohol are the most common etiologies of pancreatitis. These account for almost $80 \%$ of the cases of acute pancreatitis. ${ }^{20}$ But their incidence varies in different parts of the world. But their incidence varies in different parts of the world. Some of the Hospitalbased studies from Australia, America and India showed that incidence of non-biliary pancreatitis is more common than that of biliary pancreatitis in their institute, whereas, from Nepal, it showed a higher incidence of the biliary pancreatitis than non-biliary pancreatitis. ${ }^{3,4,20} 2122$ In our study, incidence of biliary pancreatitis is higher than that of non -biliary pancreatitis. The exact cause of this geographical variation is not well known, but growing evidence suggests that environmental and possibly genetic cofactors may also play a role in the development of AP.

In the present study, it was found that AP is more common in males than females and can affect any age, which is comparable with other studies. ${ }^{23}$ It was also found that alcohol was the main etiology in non-biliary pancreatitis and all alcoholic pancreatitis were seen in male patients, while biliary pathology was the main cause of AP in females. It is due to hormonal influence, especially estrogen, which plays an important role in gallstone formation in females, hence increases the risk of pancreatitis. ${ }^{23}$ 
MAP accounts more than $50 \%$ of the cases in most of the literature, but there is a wide range of variation in the incidence of MSAP ( ranges from $25.39 \%$ to $35.6 \%$ ) and SAP ( ranges from $4 \%$ to $25.39 \%$ ) respectively. ${ }^{21,} 24$, ${ }^{25}$ In this study, there was a higher incidence of SAP in both groups, as compared to other study, because most of the severe cases were referred cases from primary and secondary health care centers. The result we obtained also did not match with the result obtained from another tertiary care center from Kathmandu with a higher proportion of severe acute pancreatitis in both groups ${ }^{3}$.

Literature shows $30-57 \%$ of patients with AP have fluid collections with $39 \%$ of the patients having two areas involved and 33\% having three or more and about 5-21\% of patients develop necrosis of the pancreatic parenchyma or peri-pancreatic tissue or both., $21,26 \mathrm{Up}$ to $30 \%$ of patients with necrotizing pancreatitis develop infection and its incidence may increase to $70 \%$ in the third week. ${ }^{2}$ In our study, the incidence of acute fluid collection was $32.60 \%$ and $38.46 \%$ and incidence of necrosis was $23.91 \%$ and $20.51 \%$ in biliary and non-biliary group and there was no statistical difference in the incidence of infective and non-infective local complications in between these groups, which is also comparable with the data in the published literature. However, some of the studies also show that alcoholic pancreatitis tends to have more prominent peripancreatic changes than biliary pancreatitis, and higher incidence of necrotizing pancreatitis. ${ }^{11,27}$

Hemorrhagic complications are frequently encountered in routine practice following AP. The incidence of fatal haemorrhagic complications accounts for 1.2-14.5\% and incidence of pseudoaneurysm is about $3.5-10 \%{ }^{28}$

In our study there was a patient with pseudoaneurysm of gastroduodenal artery with infected pancreatic necrosis in biliary group, causing massive bleeding, which was managed with laparotomy, necrosectomy and suture ligation of GDA, later patient devlop colocutaneous fistula.

Pancreatic ascites or pancreatico peritoneal fistulas are the rare complications of acute pancreatitis. ${ }^{29}$ These are mostly seen in the patients with traumatic, chronic and alcohol induced pancreatitis, cystic duplications of biliopancreatic ducts, ampullary stenosis or ductal lithiasis. ${ }^{30,31}$ All together 4 patients developed pancreatic ascites in our study, one in biliary and 3 in non-biliary group. Incidence of local complications in our study is comparable with that of others in the literature.

Pulmonary dysfunction was the most important systemic manifestation of acute pancreatitis ranging from hypoxia to
ARDS. ${ }^{32,33}$ It is seen in $30-50 \%$ of the patients with severe pancreatitis and is regarded as one of the major factors of mortality in $22-25 \%$ of the patients and a contributing factor in an additional 30\% morbidity during the course of disease. ${ }^{33}$ It is because lung involvement is the integral part of (third phage) of the AP characterized by progression of the pancreatic injury and involvement of extrapancreatic change including SIRS and ARDS. These complications are due to production of noxious cytokines, leading to increased lung capillary permeability and decreased level of lung surfactant. ${ }^{32}$ Respiratory dysfunction precedes heart, liver and kidney failure and is responsible for the early deaths in severe pancreatitis.

The prevalence of acute renal failure (ARF) in AP ranges from $6-16 \%$ and carries a bad prognosis, especially in elderly and in those with multi-organ failure in presence of local complications. ${ }^{34,35}$ Similar to a respiratory dysfunction ARF is due to toxic injury to the kidney by release of variety of vasoactive peptides, enzymes, cytokines and other inflammatory mediators from the necrosed pancareas. Hypovolemia, decreased renal blood flow, intravascular clotting and infection also contributes to $\mathrm{ARF}^{35}$.

The mechanism of circulatory failure is poorly understood in AP. Failure in the physiological equilibrium between vasodilator (e.g. nitric oxide) and vasoconstrictor (endothelin and angiotensin) mediators have been proposed. ${ }^{36}$

Respiratory failure was the most common systemic complication in our study and there was also no significant difference in the incidence of systemic complications in both biliary and non-biliary groups, but there was some variation in the incidence systemic complications as compared with other studies. ${ }^{21}$

The need of intervention depends on the type of complications that develops after an episode of AP. Overall $12.8 \%$ AP patients required intervention. For MSAP and SAP this was $12.3 \%$ and $38.5 \%$ respectively. ${ }^{21}$ In this study, intervention was required only in SAP. For biliary etiology it was $6.52 \%$ and for non-biliary it was $10.25 \%$.

The overall incidence of mortality is $5 \% .{ }^{37}$ But this also depends on the type and severity of the disease. For MSAP mortality is $<8 \%$, whereas for SAP it can go up to $62 \% .^{37}$, ${ }^{38}$ Mortality is directly proportional to the incidence of infective complications. ${ }^{37}$ In present study mortality rate was $6.52 \%$ and $10.25 \%$ for biliary and non-biliary etiologies respectively, and there was no mortality in mild and moderate group. 
Duration of hospital stay varied according to the severity of the disease. There was difference in the median duration of hospital stay among MAP, MSAP and SAP group. ${ }^{4,21}$ In our study there was no significant difference in length of hospital stay in between the biliary and non-biliary groups. But as compare with the similar kind of study, there was a significant difference in the median duration of hospital stay in the severe group which is 24 (16-39) days, this is because of less number of interventions done in SAP in our study. ${ }^{21}$

\section{Conclusion}

Though pathogenesis vary for different etiologies, once the disease process has started, local complications, systemic complications, duration of hospital stay and mortality in AP depends on the severity of the disease irrespective of the etiology.

\section{References}

1. Carroll JK, Herrick B, Gipson T, Lee SP. Acute pancreatitis: diagnosis, prognosis, and treatment. American family physician 2007; 75(10): 1513-20. PMid:17555143

2. Beger HG, Rau BM. Severe acute pancreatitis: Clinical course and management. World journal of gastroenterology : WJG 2007; 13(38): 5043-51. https://doi.org/10.3748/wjg.v13.i38.5043 PMCid:PMC4434632

3. Bohara TP, Parajuli A, Joshi MR. Role of biochemical investigation in prediction of biliary etiology in acute pancreatitis. JNMA; journal of the Nepal Medical Association 2013; 52(189): 229-32. PMid:23591301

4. Lakhey PJ, Bhandari RS, Kafle B, Singh KP, Khakurel M. Validation of 'Moderately Severe Acute Pancreatitis' in patients with Acute Pancreatitis. JNMA; journal of the Nepal Medical Association 2013; 52(192): 580-5. PMid:25327231

5. Xin MJ, Chen H, Luo B, Sun JB. Severe acute pancreatitis in the elderly: etiology and clinical characteristics. World journalofgastroenterology: WJG2008; 14(16):2517-21. ht tps://doi.org/10.3748/wjg.14.2517 PMid:18442198 PMCid:PMC2708362

6. Lee JK, Enns R. Review of idiopathic pancreatitis. World journalofgastroenterology:WJG2007;13(47):6296-313. https://doi.org/10.3748/wjg.v13.i47.6296 PMCid:PMC4205447
7. Banks PA, Bollen TL, Dervenis C, et al. Classification of acute pancreatitis--2012: revision of the Atlanta classification and definitions by international consensus. Gut 2013; 62(1): 102-11. https://doi.org/10.1136/gutjn1-2012-302779 PMid:23100216

8. Khanna AK, Meher S, Prakash S, et al. Comparison of Ranson, Glasgow, MOSS, SIRS, BISAP, APACHEII, CTSI Scores, IL-6, CRP, and Procalcitonin in Predicting Severity, Organ Failure, Pancreatic Necrosis, and Mortality in Acute Pancreatitis. HPB surgery : a world journal of hepatic, pancreatic and biliary surgery 2013; 2013: 367581 . ht tps://doi.org/10.1155/2013/367581 PMid:24204087 PMCid:PMC3800571

9. Oller B, Armengol M, de Castro J, et al. [Correlation of etiology and severity in a series of 506 cases of acute pancreatitis]. Revista espanola de las enfermedades del aparato digestivo 1989; 76(6 Pt 2): 640-4. PMid:2633236

10. Kotan R, Posan J, Sapy P, Damjanovich L, Szentkereszty Z. [Analysis of clinical course of severe acute biliary and non biliary pancreatitis: a comparative study]. Orvosi hetilap 2010; 151(7): 265-8. https://doi.org/10.1556/OH.2010.28760 PMid:20133246

11. Lankisch PG, Assmus C, Pflichthofer D, Struckmann K, Lehnick D. Which etiology causes the most severe acute pancreatitis? International journal of pancreatology : official journal of the International Association of Pancreatology 1999; 26(2): 55-7.

12. Kim TN, Kim SB, Cho JH, Kim KH. Comparison of clinical course and outcome of acute pancreatitis according to two main etiologies: alcohol vs. gallstone. Pancreatology : official journal of the International Association of Pancreatology; 14(3): S62.

13. Bai Y, Liu Y, Jia L, et al. Severe acute pancreatitis in China: etiology and mortality in 1976 patients. Pancreas 2007; 35(3): 232-7. https://doi.org/10.1097/MPA.0b013e3180654d20 PMid: 17895843

14. de Beaux AC, Palmer KR, Carter DC. Factors influencing morbidity and mortality in acute pancreatitis; an analysis of 279 cases. Gut 1995; 37(1): 121-6. https://doi.org/10.1136/gut.37.1.121 PMid:7672660 PMCid:PMC1382782 
15. Weitz G, Woitalla J, Wellhoner P, Schmidt K, Buning J, Fellermann K. Does etiology of acute pancreatitis matter? A review of 391 consecutive episodes. JOP : Journal of the pancreas 2015; 16(2): 171-5.

16. Gullo L, Migliori M, Olah A, et al. Acute pancreatitis in five European countries: etiology and mortality. Pancreas 2002; 24(3): 223-7. https://doi.org/10.1097/00006676-200204000-00003 PMid:11893928

17. Andersen AM, Novovic S, Ersboll AK, Hansen MB. [Mortality and morbidity in patients with alcohol and biliary-induced acute pancreatitis]. Ugeskrift for laeger 2007; 169(50): 4351-4. PMid:18211793

18. Mayerle J V MC. Blumgarts surgery of the liver biliary tract and pancreas. 5th ed: Elsevier Saunders; 2012.

19. Spechler SJ, Dalton JW, Robbins AH, et al. Prevalence of normal serum amylase levels in patients with acute alcoholic pancreatitis. Digestive diseases and sciences 1983; 28(10): 865-9. https://doi.org/10.1007/BF01317034 PMid:6193932

20. Baker S. Diagnosis and management of acute pancreatitis. Critical care and resuscitation : journal of the Australasian Academy of Critical Care Medicine 2004; 6(1): 17-27. PMid:16563102

21. Nawaz H, Mounzer R, Yadav D, et al. Revised Atlanta and determinant-based classification: application in a prospective cohort of acute pancreatitis patients. The American journal of gastroenterology 2013; 108(12): 1911-7. ht tps://doi.org/10.1038/ajg.2013.348 PMid:24126632

22. Baig SJ, Rahed A, Sen S. A prospective study of the aetiology, severity and outcome of acute pancreatitis in Eastern India. Tropical gastroenterology : official journal of the Digestive Diseases Foundation 2008; 29(1): 20-2.

23. Albulushi A, Siddiqi A, Alqarshoubi I, Aladawi M, AlkhadhouriG, FarhanH.Pattern ofacute pancreatitisina tertiary care center in oman. Oman medical journal 2014; 29(5): 358-61. https://doi.org/10.5001/omj.2014.94 PMid:25337313 PMCid:PMC4202226

24. Acevedo-Piedra NG, Moya-Hoyo N, Rey-Riveiro M, et al. Validation of the determinant-based classification and revision of the Atlanta classification systems for acute pancreatitis. Clinical gastroenterology and hepatology : the official clinical practice journal of the American Gastroenterological Association 2014; 12(2): 311-6. https://doi.org/10.1016/j.cgh.2013.07.042 PMid:23958561

25. Talukdar R, Bhattacharrya A, Rao B, Sharma M, Nageshwar Reddy D. Clinical utility of the revised Atlanta classification of acute pancreatitis in a prospective cohort: have all loose ends been tied? Pancreatology : official journal of the International Association of Pancreatology 2014; 14(4): 257-62.

26. Whitcomb DC. Clinical practice. Acute pancreatitis. The NewEnglandjournalofmedicine 2006;354(20):2142-50. https://doi.org/ $10.1056 /$ NEJ M c p 054958 PMid:16707751

27. Kim YS, Kim Y, Kim SK, Rhim H. Computed tomographic differentiation between alcoholic and gallstone pancreatitis: Significance of distribution of infiltration or fluid collection. World journal of gastroenterology : WJG 2006; 12(28): 4524-8. https://doi.org/10.3748/wjg.v12.i28.4524 PMid:16874865 PMCid:PMC4125640

28. Mallick IH, Winslet MC. Vascular complications of pancreatitis. JOP : Journal of the pancreas 2004; 5(5): 328-37.

29. Erich H Jensen DB-c, Waddah B.Al-Refaie, Selwyn M Vickers. Sabiston Textbook of Surgery. In: Courtney M. Townsend RDB, B. Mark Evers, Kenneth L. Mattox, editor. Exocrine pancreas. 19th ed. USA: Elsevier Saunders; 2012. p. 1515-47.

30. Kozarek RA. Management of pancreatic ascites. Gastroenterology \& hepatology 2007; 3(5): 362-4.

31. Kalyan Kanneganti SS, Bijay Acharya, Venkatram Sindhaghatta, Sridhar Chilimuri. Successful Management of Pancreatic Ascites with both Conservative Management and Pancreatic Duct Stenting. Gastroenterology Research 2009; 2(4): 245-7. https://doi.org/10.4021/gr2009.08.1306

32. Browne GW, Pitchumoni CS. Pathophysiology of pulmonary complications of acute pancreatitis. World journal of gastroenterology : WJG 2006; 12(44): 7087-96. https://doi.org/10.3748/wjg.v12.i44.7087. PMCid:PMC4087768 
33. Raghu MG, Wig JD, Kochhar R, et al. Lung complications in acute pancreatitis. JOP : Journal of the pancreas 2007; 8(2): 177-85.

34. Tran DD, Oe PL, de Fijter CW, van der Meulen J, Cuesta MA. Acute renal failure in patients with acute pancreatitis: prevalence, risk factors, and outcome. Nephrology, dialysis, transplantation : official publication of the European Dialysis and Transplant Association - European Renal Association 1993; 8(10): 1079-84. PMid:8272219

35. B Avinash NK, AY Lakshmi, S Padmanabhan, V Siva Kumar. Acute renal failure in acute pancreatitis -role of pancreatic computed tomography severity index (CTSI). Indian Journal of Nephrology 2005; 15: 14-6.

36.Garcia M, Calvo JJ. Cardiocirculatory pathophysiological mechanisms in severe acute pancreatitis. World journal of gastrointestinal pharmacology and therapeutics 2010; 1(1): 9-14. ht tps://doi.org/10.4292/wjgpt.v1.i 1.9 PMid:21577289 PMCid:PMC3091142

37. Banks PA, Freeman ML, Practice Parameters Committee of the American College of G. Practice guidelines in acute pancreatitis. The American journal of gastroenterology 2006; 101(10): 2379-400. https://doi.org/10.1111/j.1572-0241.2006.00856.x PMid:17032204

38. Sarr MG. 2012 revision of the Atlanta classification of acute pancreatitis. Polskie Archiwum Medycyny Wewnetrznej 2013; 123(3): 118-24 https://doi.org/10.20452/pamw.1627 